\title{
Cultural Revolution as Method
}

\author{
Michael Dutton ${ }^{*}$
}

\begin{abstract}
This paper treats the Chinese Cultural Revolution as a means by which to open on to a more affective approach to the question of the political. It examines one piece of art-technology of that period and shows the way it intuitively worked within the fluidity of power to produce political intensity. This one technology is a microcosm of the Cultural Revolution notion of the political that was built around an attempt to channel and harness affective power towards revolutionary ends. Both because it attempts to direct the political through the affective dimension and because its methods of doing so resembled contemporary art practices, this paper opens on to the possibilities of a method based on an art rather than a science of the political.
\end{abstract}

Keywords: Cultural Revolution; methodology; Maoism; political; art; intensity

A movement that would "touch people to their very souls" (chuji renmen de linghun 触及人们的灵魂) was how the Party mouthpiece, Renmin ribao 人民日报 (People's Daily), described the Cultural Revolution in $1966 .{ }^{1}$ The idea stuck. A revolution that could touch people to their very souls could just as easily have been described as an "affective revolution." Affect is, after all, the experiential state that involves an active discharge of emotion leading to an augmentation or diminution of one's bodily capacity to act. ${ }^{2}$ When the "soul" is touched, bodily capacities are augmented to such a degree that affect has the potential to be transformed into a revolutionary weapon. Such a weapon is, in the language of Carl Schmitt, a form of political intensity. ${ }^{3}$

Maoism undertook a series of experiments in synaesthetic homologization to bring "idea" and "affect" into correspondence and, through that process, to "weaponize" their union. ${ }^{4}$ If Maoist "machines" brought affective energy flows

* Goldsmiths, University of London. Email: M.Dutton@gold.ac.uk.

1 "Renmin ribao shelun: wenge shi chuji renmen de linghun de weida geming" (People's Daily editorial: the Cultural Revolution is a great revolution that will touch people to their very souls), Renmin ribao, 2 June 1966.

2 This understanding of affect is drawn largely from the work of Gilles Deleuze and Felix Guattari (2004, 441) who refer to it as a discharge of emotion and as a weapon that alters a bodily capacity to act.

3 Carl Schmitt $(1996,26)$ refers to the nature of the political in the following terms: "The specific political distinction to which political actions and motives can be reduced is that between friend and enemy." He then goes on to point out that this "distinction of friend and enemy denotes the utmost degree of intensity of a union or separation, of an association or disassociation."

4 Benedict de Spinoza makes the distinction between idea and affect in Axiom 3, Section 2, of Ethics, when he notes that while modes of thinking about, say, love cannot exist without an idea of the 
to the surface as a clustering of intensely felt political ideas, it did so by channelling them through the ever narrowing vector of the friend/enemy dyadic structure of the political. ${ }^{5}$ This was to enable the velocity and intensity of the affective flow to be constantly and rapidly increased.

The Cultural Revolution, as the apogee of this experiment in deploying affective revolutionary technology, has come to be regarded as a disaster for China, but if the various attempts to harness affective energy flows and channel them towards a productive intensity were understood as being the basis of a particular and unique mode of being political, then this disaster opens onto a new way of understanding the dynamics propelling the Maoist political on the ground, and offers an entirely different focus to the ongoing theoretical debate about the Schmittian political. ${ }^{6}$

It suggests that rather than focusing on questions of representation - which was the locus of Schmitt's work - the concept of the political demands that attention needs to be re-directed towards the more ethereal question of politico-affective flows and the technologies that "guide" them. ${ }^{7}$ This re-alignment fundamentally alters the way we might begin to look at Maoist politics. It suggests that each mass-line Maoist political campaign, far from being a smokescreen disguising the "real" politics taking place behind the scenes was, in fact, the key to understanding the dynamics propelling this mode of politics. This is because it operated as a key technology for the channelling and harnessing of the affective flow into an overtly political form. It also suggests that work in the cultural and aesthetic realm, far from being merely epiphenomenal propaganda, was actually central to the construction of the political, for Maoist China was the site of an experiment designed to calibrate an approach to political transformation through the channelling of the affective flow. Moreover, it also suggests that, collectively, these technologies, perhaps even more than the battles taking place between individual

\footnotetext{
footnote continued
}

thing loved, the idea of love can itself exist separately from the state of being loved. See Spinoza 2015. Drawing on this, Gilles Delueze (1978) notes that ideas are representational whereas affects are not. The Maoist "trick" was to weave them into one form.

5 The friend/enemy distinction is, of course, what Carl Schmitt calls the unique criteria "to which all action with a specifically political meaning can be traced" (Schmitt 1996, 26). As I have shown elsewhere, this duality can be traced all the way to China where it would sit at the heart of the Maoist political. On the centrality of this to the Maoist political, see Dutton 2005.

6 For Schmitt, this friend/enemy distinction was always concrete, rather than metaphoric or symbolic (Schmitt 1996, 27), leading Jacques Derrida to claim that "the political is only available as practical identification" (Derrida 1997, 117). In other words, the political in Schmitt always takes a representational form. By focusing on the transformation of affective energy flows into a political intensity, the political comes to centre upon the non-representational "fluid" aspects.

7 For Schmitt, the jurist, it was the manifestation of intensity as "solids," structures or "things" - be they institutional forms, like state organs, concepts, like friend and enemy, or juridical concepts such as sovereignty - that became the focus of the concept of the political. The centrality of the concept of representation to Schmitt's thinking can be gleaned from one of his early works written (in 1923) before he developed the concept of the political. Simona Draghici $(1988,23)$ in the introduction to that work (Schmitt 1988) suggests that the concept of representation was so important to Schmitt that he not only wrote about it but also took on a PhD student to research the question further. 
"leading figures" within the conventional political realm or the factional struggles taking place within institutional sites, hold the key to understanding the dynamic propelling the Maoist political. If that holds true, then this has ramifications not just for our understanding of the dynamics of Maoist politics but also more generally for the very definition of the political. To unearth this aspect of the political, however, requires an altogether different approach to the question. In short, it requires an approach that could be termed an art of the political.

An art of the political is neither a political science nor simply a mentality of government (governmentality). ${ }^{8}$ Rather, it turns on understanding a set of culturally and site-specific process-driven practices and machines that intuitively work within the fluidity of power to produce political outcomes. Directional rather than intentional, an art of the political focuses on those social technologies that attempt to channel, harness and make concrete the fluidity of the affective realm. ${ }^{9}$ An art of the political focuses on the channelling mechanisms that encounter the heterological, intangible and affective flows, and either turns them into political intensities or dissipates them by other means. An art of the political is, then, concerned with those technologies that work either to intensify or to de-intensify the power of an affective energy flow. If commodity markets are the central means by which such flows are de-intensified and dissipated in our world, the Cultural Revolution opens on to the technologies and machinery of class struggle designed to produce and expand the production of political intensity in theirs.

Collectively, these technologies of the Cultural Revolution worked to turn the rational cognitive processes that produced a strong intellectual belief in revolution into goosebumps on the surface of the skin, lumps in the back of the throat, tears in the eyes of the believer, and anger in the heart of the revolutionary. ${ }^{10}$ The novelty and invention of this Maoist political apparatus lies precisely in its experimentation with technologies of fusion that brought together and intensified idea and affect. It would lead to thought being pushed into excess, action into "chaos" and reason into "madness," all through the singular focus being placed on fighting the (class) "enemy." 11 If that class-based focus on tapping into and channelling this affective flow led to people being touched to their very souls, the binary

8 This is not to reject the notion of governmentality but merely to note a limit on thinking of this flow as being restricted to matters of government. Rather than a mentality, this form of thinking in some ways resembles the broader frame that Edward Said has called a "style of thought," which, he notes, informs all writing, thinking and acting on "the Orient." Having said this, it should also be acknowledged that the rendition of the political given here draws heavily on the Foucauldian insistence that power is fluid, mobile and relational rather than "a thing." On governmentality, see Foucault 1991. On the Said notion of a style of thought, see his description of Orientalism in Said 1978, 12. On Foucault's rendition of power as fluid, see Foucault 1978, 94-95.

9 It could, perhaps, in the language of Delueze and Guattari, be called a (political) "becoming." For details of how this might be the case, see Massumi 1992, 94-95.

10 How these are "measured," and thereby become unfelt in our world, is described in Massumi 1995, 83-109.

11 Massumi $(1995,85)$ notes the way intensity is always organized around an either/or. 
logic being deployed produced the occasional violent intensity that left some very deep scars.

With varying degrees of moral indignation and intensity, China area studies scholarship has been picking away at these scars ever since. Picking at scars led to stories of abuse that resulted in widespread disenchantment and revulsion. As the critiques mounted, they buried any claims to the Cultural Revolution being a socio-political experiment. All it seemed to have done, it appeared to suggest, was scar a generation. Whether that generation is scarred or genuinely touched, is, however, in terms of political theory at least, less significant than the fact that it "affected" them. That is to say, in marking the soul, it moved the question of class struggle beyond the rational, homogenous realm and into the realm of affect. It was here, in this realm of the heterological, that the socio-political affective revolutionary experiments of the Cultural Revolution took place. These experiments were, in a sense, being carried out "underground" for they were buried within a concept of the political that was itself embedded within a discourse of Maoist revolutionary experiment.

Maoism would never speak of this "affective" revolutionary experiment directly for it was regarded as little other than a set of techniques or means to an end, and that end was the manifest revolutionary experiment extending around the category of class struggle. Yet, under this other language game centring on the words "class struggle," a "style of thought" could be discerned that revealed affective dimensions within a series of symptomatically linked practices, ideas and techniques Maoism either devised or developed.

What was the nationwide, rhythmic, mass campaign if not an expression of a guiding process being imposed upon a pulsating energy force designed to build into a political intensity? How could one understand the Maoist notion of continuous revolution without an intuitive grasp of the fluidity of power and the political? How could one understand micro-level techniques such as typification and the formation of "models" without an appreciation of how political anthropomorphism led to a condensation and intensification of the figure of the (typified) enemy? Together, these and other techniques that aimed to touch the soul worked within what has been referred to as the "one big concept" of Maoism.

This term, "one big concept," comes neither from Mao or Maoism but from the conceptual artist Cai Guoqiang 蔡国强 as he reflected upon the power of one Maoist "model" artwork that he re-worked for the Venice Biennale of 1999. That original artwork was called the Rent Collection Courtyard and, when unveiled during the Cultural Revolution, it was said to "reflect a true picture of the soul-stirring (jingxin dongpo 惊心动魄) struggle of the old society in the countryside." 12 It was a monumental work - being 118 metres long and featuring 114 life-sized mud statues - and profoundly political in nature: it was

12 "Shouzuyuan, chuanbu nisu zhongxin fanzhi zai Beizhanchu" (Reproductions of all the clay statues of the Rent Collection Courtyard go on exhibition in Beijing), Renmin ribao, 3 December 1966. 
proclaimed a "model" for the plastic arts at the beginning of the Cultural Revolution in $1966 .{ }^{13}$

Housed in the central courtyard of the Manor House Museum of a former Sichuan landlord, Liu Wencai 刘文彩, in the township of Anren 安仁, the Rent Collection Courtyard was of interest to Cai less for its manifest politics than for its material form. The unstable nature of the un-kiln dried mud statues enabled Cai to interrogate processes of creation and destruction as the mud cracked and fell away from the surfaces of his remade Rent Collection statues in Venice. Where the original had been a "finished" set of figurative and realist art-objects designed to tug on the emotions and channel political intensity through a narrative description of the ongoing class struggle in the countryside, Cai's Venice Rent Collection Courtyard re-focused the work on the more abstract, contemplative question of flow. Cai's partially completed, completed and slowly deteriorating mud statues were inspired by a Taoist notion of cyclical birth, life and death flows. ${ }^{14}$ His focus on the power of flow was anchored to the impermanency of the statues' material form. Mud would dry and crack and, as it did, the cyclical flow of the Taoist notion of birth, life and death came to the fore. By bringing the question of flow to the surface, Cai's work helps us to understand its function within the original work, but it is his memory of what inspired his interest in this original Maoist work that brings us back to the question of the affective element in any life flow:

When I was a schoolboy and first saw the Rent Collection Courtyard, I was moved by the adult next to me who looked at it and cried because he had really suffered at the hands of his landlord. I felt his pain. The exhibition guides who explained the story of the Rent Collection Courtyard to [our class] also cried as they spoke ... and when they cried, the whole class began to cry. They gave us some really inedible food that tasted like straw, and they explained that this was a peasant staple in the old society. We forced down the food and, with tears in our eyes, looked at the statues as the severe hardships of the old society were explained to us. Now that I look back on this from an artistic point of view, this whole thing is really interesting. It was a work not just about statues, but about the tears of the guide who explained things, and the horror of the disgusting food we were being forced to eat ... These things were all part of the same big concept. ${ }^{15}$

The statues, the tears, the food and the horror were existentially felt effects tied together and intensified by the same big concept. It was this one, big, politico-affective concept that Cai's conceptual art replaced with its own particular focus on flow. Yet, despite the evisceration of the "narrative string" that had held in place the affective, cathartic and political dimensions of the original work, Cai's re-working still functioned like a palimpsest revealing the shadowy traces of the original focus of the work in the faces of his slowly deteriorating mud

13 See Erickson 2010, 123. For an excellent English language account that contextualizes the Rent Collection Courtyard within the Manor House series of exhibits, see Lee 2014, 197-242.

14 As Anne Wedell-Wedellsborg says, it involved "questions of authenticity/originality/copying in art works as well as formal copyright, of socialist realism versus postmodernism, of the process of creation and destruction, individual and collective, of timelines, context and site specificity, of local and global, of the concept of aura, and of course again of different expectations, China versus the West." See Wedell-Wedellsborg 2010.

15 Interview with Cai Guoqiang, New York, 24 March 2010. 
statues. ${ }^{16}$ By removing the narrative thread, Cai's reconstruction enabled the focus to shift to the process of production rather than to the finished product or content. In de-centring the original work's (political) content and replacing it with a focus on the act of making, Cai Guoqiang's process-based work could well be accused of being an aestheticization of the political. Oddly, however, it was precisely because Cai shifted the focus of his work out of the space of an overt Maoist political aesthetic and into the more abstract space of contemporary art that he was able to reveal some of the key techniques of the original work. By shining the spotlight on process - here meaning not just the technical process of sculpting but the panoply of process-based techniques employed by the original Maoist sculptors to create the work - the mechanisms devised to channel the affective flow of the political towards a cathartic intensity begins to come into focus. Developed in unison with other techniques designed to channel and intensify the flow, the original Rent Collection Courtyard statues reveal a certain machine-like quality in the way they produced this effect.

This is not the machine art of Vladimir Tatlin designed to cognitively estrange, but the art-machine of Maoism designed to draw in and emotionally inspire and direct. ${ }^{17}$ Where Tatlin's work was produced in the age of steel and made to make iron "stand on its hind legs" and seek an artistic formula, ${ }^{18}$ these statues were made of mud and drew upon the telluric techniques of the peasant artisan wed to the didacticism of a theatrically based political narrative. It was artisanship rather than artistry, mud rather than steel, and it was the art of emotional identification rather than an art of estrangement or contemplation. A cognitive understanding of the Rent Collection Courtyard story line was insufficient for the goal was to produce a work that would be intensely felt as well as understood.

Working within another machine - the Manor House Museum - the Rent Collection Courtyard exhibition was designed to lead to one single political effect: the raising of revolutionary consciousness. These were technologies of political intensification, not estrangement, and they were attempting to weave together multiple and parallel strands and flows into one big concept. The original sculptors worked to intensify the emotional effect of the Rent Collection Courtyard by

16 Faces were important to the sculptors of the Rent Collection Courtyard. Long Taicheng, who worked on the original statues and was then chosen to go to Beijing and work on the reproductions being made there, explains: "When I went to Beijing to reproduce the statues, I had to observe numerous faces. Every day as we took the bus from Hepingli to the Art Museum, we observed many northern boys' faces. In my work, I tried to mix the faces of northern boys with those from the south. I also studied their expressions of anger and resistance. They looked very different from the anger and resistance being displayed on the faces of adults." Interview with Long Taicheng, Chongqing, 21 August 2011.

17 It was Victor Shklovsky who spoke of Tatlin's Tower as being an "architecture of estrangement." According to Svetlana Boym, this notion of ostranenie, or estrangement, suggested both a distancing (dislocating, depaysement) and making strange. For an elaboration on this, see Boym 2008, 18-19.

18 Once again, these are the words of Shklovsky $(2005,69-70)$. The association of Tatlin and machine art, however, comes from the Dadaists. It was at the Berlin Dadaist Fair of May 1920 that two of the founders of the Dadaist movement, George Grosz and John Heartfield (Helmut Herzfeld), held up a large placard taken down from the gallery wall with the slogan, "Art is Dead - Long Live Tatlin's Machine Art" written across it. They were then famously photographed holding up the placard. For them, Machinenkunst flagged the death of art. For details, see Lynton 2009, 30-67. See also Tafuri 1990, 136. 
collecting, editing and weaving together into a single tale the numerous stories of exploitation peasants suffered at the hands of their landlords. ${ }^{19}$ Intensification was not a depiction of real events but of real affects. This would involve remodelling peasant gestures not on the gestures of "real life" peasants but on "typifications" of such gestures modelled by actors of a Sichuan Opera troupe. Their gestures and comportment signified a stylized and intensified bodily form used for dramatic effect ${ }^{20}$ and purposively designed to produce crying, anger and enthusiasm ( $j$ in 劲) as a response. ${ }^{21}$

This Maoist artwork did more than just convey a message in mud: it attempted to inscribe this message emotionally in the audience's mind. More than that, it also wanted to mould politically the artists sculpting the mud statues. Through a very different process-driven practice to that which informs conceptual art, the original sculptors became imbricated in the transformation process. As $\mathrm{Li}$ Shaoyan 李少言 pointed out: “The process of creation was also a process of thought reform for the artists concerned." 22 In other words, the making of this work involved a much broader set of transformative processes than the sculpting of mud. The ethnographic fieldwork necessary to produce a plot-line that would touch the peasants "to their souls" demanded that the sculptors themselves be touched. To be touched, the sculptors would have to bury themselves in the peasant life they were depicting. They had to live with the peasants to understand existentially the life they lived, and it was this experience that would then have ontological effects upon them and transform their work own styles.

From the peasants, the sculptors not only learned the indigenous techniques of mud statue making, they also learned a pedagogy of frugality and self-reliance. These techniques would be used to alter the practices of these classically trained "academic" sculptors. Moreover, the demand that this be a collective rather than individual enterprise forced these sculptors not just to reflect upon their craft but also upon their own work practices within art.

As an artwork machine created specifically to channel the flow of the political, the Rent Collection Courtyard was, therefore, to have cognitive effects upon those who worked on the design and production of these statues as well as upon the viewing public. The work required intense thought being given to the emotional effects these material objects would have upon the masses. "Wax statues in the

19 Wang, Zhi'an 2001, 159, 163.

20 Interview with Zhao Shutong, one of the original lead sculptors on the project, Chengdu, 19 August 2011. See also Wang, Zhi'an 2001, 165.

21 These are the "emotions" that the sculptors of the original Rent Collection Courtyard decided to focus on and "produce" through the artwork they were creating. For further details on the way they attempted to tap into these emotions, see Wang, Zhi'an 2001, 202.

22 Li Shaoyan, who was head of the Sichuan "arts council" (meixie) at the time, made these remarks in relation to the weight being placed on the collective nature of the enterprise, which, he claimed, helped combat the individualism of the artist $(\mathrm{Li} \mathrm{1965,6).} \mathrm{But} \mathrm{he} \mathrm{was} \mathrm{not} \mathrm{the} \mathrm{only} \mathrm{one.} \mathrm{Ma} \mathrm{Li}$, who was the Wenjiang area committee propaganda ministry chief at the time, addressed the sculptors saying that, "in going through the process of creating this work, you also go through your own type of ideological reform, and towards your world view, and view of humanity, you undergo your own huge revolution" (Wang, Zhi'an 2001, 191). 
exhibition offer gloomy, frightful figures that evoke real fear" one sculptor would say ... "ahh yes, but the reality of the old society was about a hundred times gloomier and more frightful" came the reply, and so the debate on appearance and its ability to carry a strong political message continued. ${ }^{23}$ It required experimenting with various indigenous materials and knowledge forms to "place" the work, not just in a site-specific location, but within a style of thought that was readily intelligible to ordinary rural people.

Using everyday materials and motifs that local people were familiar with meant learning from the masses. "From April 1965 onwards, I understood our role as being to offer support, which meant 'learn at work and work in learning' (gongzuo zhong xuexi, xuexi zhong gongzuo 工作中学习, 学习中工作), the Western-trained lead sculptor of the project, Zhao Shudong 赵树同, would say. ${ }^{24}$ It meant living and working with peasants, developing a sense of selfreliance, and adopting a collectivist and self-critical attitude towards oneself and one's work. Lastly, it required an attitudinal change such that challenges and hardships encountered in the process of making the work were treated as part of the work. It was an honour bestowed rather than a burden carried. "In those days it was really hard ... things were really hard but no one had any demands because, from our perspective, we felt really honoured" junior sculptor on the project, Long Taicheng 隆太成, said. ${ }^{25}$ The process was profoundly experiential and utterly Maoist. Indeed, it was another example of "greater, faster, better, [and] more economical" production (duokuaihaosheng 多快好省) being operationalized, but this time in mud rather than in the economy.

The sheer scale of the project made it "greater" (duo 多). The honour felt by young sculptors such as Long Taicheng was harnessed by a Stakhanovite-like work drive that led them to produce this massive work in just four and a half months (faster - kuai 快). The use of simple, cheap and indigenous-based artisan technologies brought a new economy to the usually expensive art of figurative sculpture, reducing the cost of each statue to just three yuan per statue (economical - sheng 省). ${ }^{26}$ Moreover, through the fusion of modern political energy with figurative art practices merged with demotic indigenous telluric technologies, the plastic arts themselves would be transformed (better - hao 好).

"It is a revolution in sculpting," crowed the official Party organ, the Renmin ribao. Declared a "model work" by Mao's wife, Jiang Qing 江青, the original Rent Collection Courtyard would be hailed as the harbinger and prototype of a

23 Wang, Zhi'an 2001, 140.

24 According to Paul Clark $(2008,206)$, the statues were made by teachers and students of the Sichuan Academy of the Arts, but that is not entirely true as peasant artisans were involved. Indeed, according to Zhao Shutong, the indigenous element, not the academy, played the primary role. The role of the Academy in the construction of this suite of statues, he asserted, has been overstated by others such as the other leading sculptor on the project, Wang Guangyi. Interview, Zhao Shutong.

25 Interview, Long Taicheng.

26 Three yuan is the figure given in Renmin ribao, 6 November 1965. On today's exchange rates, that is less than US 50 cents per statue. 
new revolutionary practice in the plastic arts. ${ }^{27}$ What it shared with the other “model," or yangban 样板, artworks was that, like them, it was designed to channel and heighten political intensity in a manner that would, simultaneously, stretch the boundaries of the art form it worked within by fusing modern and indigenous telluric technology and knowledge. ${ }^{28}$

Such fusion practices - that brought the telluric into the modern - stretched well beyond the arts to include all those things that were labelled "socialist new things." The "new medical methods" of Maoism, for example, demonstrated a similar re-alignment and fusion of modern Western medical techniques with traditional Chinese medicinal practices to produce a new model for medical science. ${ }^{29}$ Model art, model science, model theatre - this concept of the model, as Børge Bakken demonstrates, is deeply embedded in traditional Chinese cultural practices and spreads into educational and even social-control discourses. ${ }^{30}$ What turned model-making from a tradition into a revolutionary practice, however, was not just the ability to set a norm but also its capacity to turn that norm into a device to incite class-based feelings of love and hatred.

Typification was used both to produce positive love and also to generate hatred. Negative models, such as the landlord Liu Wencai in the Rent Collection Courtyard, were created by building upon the "proper name" such that it came to embody all the negative traits of the particular class they represented. The narrative string holding such a biography together would be based on the revealed tales of exploitation and excess. Endless stories tipped into the single figure of Liu Wencai erupted into a single political torrent. The unity of the proper name and the typified life intensified the effect: "When the labouring masses viewed this work, they remembered suffering so much pain that they lost their voices (tongku shusheng 痛苦失声) but simultaneously developed a heightened sense of class hatred," said the Renmin ribao. ${ }^{31}$ Even before completion, this artwork seemed to touch raw nerves: "Because we left the courtyard gate open when we were working, a lot of the peasants got a sneak preview and when they were

27 In February 1966, Jiang Qing identified the Rent Collection Courtyard as a model for other artists to emulate in a speech entitled "Summary of the forum on literature and art in the armed forces with which comrade Lin Piao entrusted Chiang Ch'ing." Chung and Miller 1968, 208. For further commentary on this work as a model, see Zhang 2005, 46.

28 Paul Clark claims that the model operas made just these sorts of claims and that was what made them "models." While not untrue, the key thing that made models exemplary was that each constituted a machine component within what one might call, to steal a line from the Dadaist about Taitlin, a machine-art form. This made Maoist art-forms technologies for the channelling and intensification of the flow into a single political cathartic end. For a more prosaic account of the characteristics that led to them being technologies of the flow, see Clark 2008, 57-58, 73-75.

29 On Maoist innovations in medicine, see Beijing City Hygiene Bureau Small Leadership Group of the Revolutionary Committee of the Beijing Number Two Hospital 1969.

30 Børge Bakken traces this penchant for the model, the typification and the exemplary back to traditional times, noting that Chinese pedagogy contains a "fundamental assumption ... that people are capable of learning from models." Bakken 2000, 8. Ouyang Zongshu on Chinese genealogical records illustrates this with reference to the exemplary ancestors being used as models for future generations in the late dynastic period (Ouyang 1992). For further details on how this late dynastic tradition fed into the Maoist pedagogy, see Dutton 2004.

31 "Shouzuyuan" (The Rent Collection Courtyard), Renmin ribao, 6 November 1965. 
invited in they were intensely aroused (qunqing jifen 群情激奋) and choked back their tears (qibuchengsheng 泣不成声). Some even fainting (hundao zaidi 昏倒在地),” said one of the leading sculptors, Wang Guanyi 王官乙. ${ }^{32}$

To produce this effect, the Rent Collection Courtyard could only work within a very specific cultural milieu in which the one big concept propelled all affective energy streams towards an intense political conclusion. Indeed, the art-ful-ness of the original Rent Collection Courtyard project lay not in the realm of aesthetic appreciation or estrangement but in the channelling function it performed within a particular overarching political culture. Its artfulness in this particular politicocultural milieu led to it operating as a catalyst for the harnessing of emotions such that they would intertwine and be channelled into a single and powerful political intensity.

Like the "new medical methods," the Rent Collection Courtyard project attempted to touch people to their souls by pressing upon key political affective pressure points. This method took it beyond an appreciation of a cognitive-based knowledge regime that offered an account of past oppression and attempted instead to reproduce, in facsimile, the taste, tears and pain of past suffering via a mud-based "condensation" of the rural class struggle. ${ }^{33}$ Peasants fainting as they saw their own pasts caught in mud; silent pain developing into class hated; teardrops welling in a schoolboy's eye as food was ingested but proved to be hard to swallow because of the crimes of the evil landlord, Liu Wencai. These were just a few of the physical manifestations of a visceral connection being created between cognitive and affective states of being. These affective states were not simply based upon "revelation" but produced through a manipulation and channelling of the affective energy flow that surfaced as a series of powerful emotions connected ultimately to a political campaign.

Sipping his tea and talking to the artists while they sculpted the work, the local Party chief and patron of the work, Ma Li 马力, said: "Concerning the creation of the Rent Collection Courtyard, I want to raise a small request. The spirit (qifen 气氛) of the overall statues needs to be grasped and grasped accurately, for the aim of this work is to lay stress on the overwhelmingly positive aspects and if this healthy trend does not prevail, then a perverse or evil energy flow (xieqi 邪气) will." 34 The evil energy flow of the landlord "enemy" would, therefore, not be the central driving force of this political narrative. ${ }^{35}$ Rather, the enemy

32 Wang, Guanyi 1996, 38.

33 Renmin ribao said that: "We have many young people in this country who have seen the reality of man's exploitation of man, and man's oppression of man. And even though many people have obviously seen this, it was quite a while ago and the influence of this upon them has grown ever more faint. So the role of these mass clay statues, in reflecting the leadership of Mao Zedong thought, is to awaken people from their light sleep and to get them to rise up, getting them to recognize and reflect upon the fact that the old society acted against the people's interests, and from this vantage point strengthened their love of the current new society of socialism." See "Shouzuyuan" (The Rent Collection Courtyard), Renmin ribao, 11 June 1965 .

34 Ma Li, quoted in Wang, Zhi'an 2001, 191.

35 This tends to contradict the important point made by Leo Strauss on Schmitt's work, which suggests that the enemy is always philosophically central. See Strauss 1996. 
would be used to catapult the peasants into a realization that there was a need for their energy to be directed, guided and organized. Tears would be shed, remembrances of past horrors would flood in, and all the feelings of humiliation and misery would be gathered together pointing, inexorably, to one solution: the need for revolutionary organization. That is, it would point to the need for a friend. ${ }^{36}$ To reach that conclusion, the original statues were designed to transcend logical-cognitive connections and tap into the affective flow to release three key emotions - crying, hatred (chouhen 仇恨), and strength or drive (jin 劲):

[If] we want the masses, when viewing the Rent Collection Courtyard, to think about old China ... then, in emotional terms, we need to induce three emotional changes within them: crying, enmity, and drive.

Crying - this would deeply arouse the masses, allowing for the production of a mass consciousness by moving them with feelings of tragedy.

Enmity - here we wanted the audience to hate the landlord class, hate reactionaries, and hate the old society.

Drive - after undergoing “speak bitterness” sessions ( yiku sitian 忆苦思甜), the people would be inspired to a higher class consciousness, transforming their class hatred into a form of powerful resistance. $^{37}$

It was in the penultimate section of the original Rent Collection Courtyard work entitled "resistance" (fankang 反抗), that crying and hatred would be transformed into strength and drive. Wang Zhi'an 王治安 explains how these energy flows were channelled through these emotional states into a unidirectional torrent:

The final section of the work was themed "resistance" (fankang) and the key point here was enmity (chouhen) - the enmity of the peasants towards the landlord. Here, there was a selfgenerating notion of struggle tied to a growing consciousness of that struggle. Hence, [enmity and resistance] were two halves of the same coin: one expressed an abstract "hatred" (hen 恨); the other, the peasants' growing self-awareness of where that hatred would lead. Here, the idea of hate is expressed as a form of spontaneity (zifaxing 自发性), while the growing peasant self-awareness pointed towards organization. ${ }^{38}$

To understand, concretely, how the channelling of spontaneity and self-awareness could produce revolutionary organization, the artists packed their bags and went and lived in a former partisan basecamp known locally as "little Yan'an."39 There, they lived a spartan peasant life, sharing the food of the peasants and working alongside them in their labours. "This was all part of the creative process,” lead local sculptor, Li Qisheng 李奇生, would insist. ${ }^{40}$

36 Here, then, we witness a very important theoretical shift taking place. "Of the two elements of the friend-enemy mode of viewing things, the 'enemy' element manifestly takes precedence." Strauss tells us about Schmitt (Strauss 1996, 88). For Ma Li and the Maoists, things are different. For Ma Li, the enemy is a "tool" to be used to promote class struggle. Moreover, from Ma Li's warning about not allowing "evil energy" to prevail, right through to the sequencing of the Rent Collection Courtyard statues leading to the victory of the "collective friend" (the revolutionary organization), the enemy is rendered as the propellant pushing forward the victory of the friend.

37 Wang, Zhi'an 2001, 202. Author's translation.

38 Ibid., 210.

39 The official name of the place they went to was Three Junction Commune (Sancha gongshe). Originally, it was the underground basecamp of the west Sichuan Communist Party branch. See Wang, Zhi'an 2001,163 , for further details.

40 Ibid., 162-63. 
This experience of living, working and struggling alongside the peasants was all part of a Maoist pedagogy and, when combined with the use of mud and indigenous technology and knowledge, produced the telluric conditions for a political transformation that was constantly being contexualized in terms of an idealized view of peasant life as intrinsically revolutionary.

The use of "found objects" in the Rent Collection Courtyard project such as desks, an abacus and a grain thrasher, the employment of site specificity by using the courtyard of the landlord's manor house as a stage, and the leaning of mud statues on doorways or against structural pillars - all these novel art innovations came not from conceptual art theory but out of a profoundly Maoist sense of "making do." Making mud statues, then, was far more complex and process-based than the final sculpted work might suggest. The entire process, however, was designed to produce a political effect. It was, in fact, part of the "one big concept" of Maoism, to return to Cai's phrase, and that could only be imagined in terms of affective productivity operating within a larger sociopolitical context particular to that time, place and culture. In that sense, this work raises the question of site specificity in two ways.

First, in terms of the broader society, this form of art-incitement could only work when the overall regime of veridiction was political rather than market based. In other words, the Rent Collection Courtyard was "site specific" in terms of the revolutionary regime of veridiction that required the production, reproduction and harnessing of poetic-political intensities wedding to both cognitive and affective flows. Within that society, this artwork was designed principally around the gathering and channelling of an affective flow so that it would and could be transformed into a political torrent.

Second, in terms of the local context, the original mud statues must be considered in terms of their role within Liu Wencai's manor house. Here, in its original form, the Rent Collection Courtyard art machine was but one (albeit penultimate) technology within a larger machine known as the Landlord Manor House Museum. Once again, site specificity takes on a particularly political hue for it was art technologies like the Rent Collection Courtyard project that helped to transform Liu Wencai's manor house into what the Maoists at the time would come to call a classroom of class struggle. ${ }^{41}$ Yet, even this classroom had a pedagogy that could only operate in the broader context of the Cultural Revolution as one of many machines that would politicize the entire social landscape.

This is not to suggest that these machines always worked. On the contrary, an economy of flows is constantly and permanently shadowed by leakage. Yet, leakages in this regime were potentially productive. Leakages, read symptomatically, often spelled out the word "enemy," which in turn broadened the field of class struggle. Within Maoism, the more these machines leaked, the more they patterned the nature of the class struggle. In other words, through leakages, these

41 Wang Zhi'an describes the manor house as a classroom for class education in his book. Ibid., 19. 
machines potentially produced the conditions for their own extended use. The Rent Collection Courtyard, therefore, is much more than a Maoist timepiece of the Cultural Revolution. It is an artefact of another mode of being political and a window opening onto an understanding of that other mode.

In disposing of affective energy flows by intensifying them, this mode of the political operated along very different vectors to those forms of the political that employed the phantasmagoric to turn intensity into commodity desire. Technologies such as the Rent Collection Courtyard, therefore, required reconditioning when the channelling of affective flows was no longer tied to the intensity of class struggle but was instead dispersed and diffused through market fetishization. It was in the transformation of machinery like the Rent Collection Courtyard that the legacy of the Cultural Revolution moment reveals itself.

Just as Cai Guoqiang moved the Rent Collection Courtyard out of figurative and into conceptual art by changing the location, so too market reforms would transform the Rent Collection Courtyard exhibition from a political into an aesthetic machine by a process of mimetic reconfiguration. In the reform era, Liu Wencai's manor house was re-defined as an important feudal-era historic relic, ${ }^{42}$ rather than a classroom of class struggle. This process involved transforming the central courtyard that housed the Rent Collection Courtyard into an art space. Behind glass, in a temperature-controlled, softly lit gallery space, the Rent Collection Courtyard statues entered the white cube. Here was politics transformed into aesthetics through a process of mimetic reconfiguration of the entire Manor House site. Similar mimetic transformations were visited upon Chinese policing practices, ${ }^{43}$ government bureaucracies ${ }^{44}$ and the operations of businesses. ${ }^{45}$ These transformations reveal more than the mimetic faculty of government; they reveal the continuing concern that government displays with the channelling of the affective flow. In the current era, however, any machinery with a capacity to generate political intensity is to be disabled, dismembered, diffused, transformed or repressed. With market veridiction at the heart of the reform system, attempts to disable and transform the Manor House machinery offer one small example of this new political focus. It is this process of transformation that reveals the lasting legacy of the Cultural Revolution as a mentality of government still essentially concerned with the policing of the flow. This continued preoccupation with the channelling of affective flows has, in recent years,

42 "A typical reflection of the nature and architectural form of landlord class estates in Sichuan in the modern era" which "epitomises the rise and fall of feudal class production in the modern era of China" was how Wang Zhi'an, Wang Fei and Wang Shao describe it. See Wang, Zhi'an, Wang and Wang 2003, 103-04.

43 The redeployment of Maoist movement structures into law and order campaigns is dealt with in Dutton 2002, while the role of the contract in transforming the mass line is addressed in Dutton 2005.

44 Traits that have been termed a "guerrilla policy style" by Sebastian Heilmann and Elizabeth Perry are said to persist in the reform era. Heilmann and Perry 2011, 12.

45 The operations of the company Hua Wei are founded on notions of self-criticism and self-reliance, learned by the company's founders through years of experience of the Maoist-inspired ethics of the Chinese army. See Cheng and Liu 2003. 
however, moved beyond the mimetic transformation of inherited relics and old practices and come to inform contemporary governmental practices in relation to new areas of concern. The internet offers the clearest example of this ongoing concern.

In a recent series of quantitative studies of internet censorship covering over 11 million social media posts from almost 1,400 websites across China, Gary King, Jennifer Pan and Margaret E. Roberts demonstrate this preoccupation in current Chinese government censorship strategies. Contrary to most Western accounts of Chinese censorship as crude and unsuccessful attempts to ban dissent, their studies show that the Chinese censors are less concerned about dissent than about blogs leading to potential collective street-level action. Blogs and sites that attract large numbers of hits and are deemed to have a potential for collective social action are subject to censorship and this is irrespective of whether such blogs foster or fight with the Communist Party. ${ }^{46}$

Chinese government censors, they note, redact pro-government posts and antigovernment posts, for their aim is not to stifle criticism but to halt internet viral bursts that could lead to collective political action. ${ }^{47}$ To this end, the progovernment “50 cent army" (wumaodang 五毛党) bloggers are dispatched not to bombard viral sites with pro-government propaganda and thereby raise the degree of political intensity by heightening the friend-enemy antagonism, but rather to lure traffic away from such sites towards ones with less collective political action potential. ${ }^{48}$ In other words, the Chinese censorship strategy is built around halting the eruption of political intensities and not stamping out all criticism. ${ }^{49}$ Achieving this end involves, once again, channelling and harnessing affective flows, but unlike the Cultural Revolution, this time the focus is on de-intensification. Nevertheless, it is still a politics that has, as its key compass point, the friend and enemy grouping. Both in the Maoist era and in the reform era, it is still a policing of the affective flow that sculpts the political imagination. The sensitivity around the question of the Cultural Revolution in contemporary China today is, perhaps, a sign of just how deeply the Chinese imagination has been marked by this question of political intensities. The most evocative legacy of the Cultural Revolution, perhaps, is this haunting presence; captured not in words, records or material forms, but in a continued and quite different mentality of government that is still tied to the harnessing and channelling of affective flows.

\section{Acknowledgement}

The author wishes to thank Stacy Lo for her help with research and translation, Deborah Kessler for help with proof reading and comments, and Chris Berry,

46 See King, Pan and Roberts 2013, 327.

47 King 2013.

48 King 2013.

49 See King, Pan and Roberts 2013; 2014. 
Patricia Thornton and Harriet Evans for their comments and their original invitation to present this at the Cultural Revolution Legacy workshop organized by The China Quarterly in 2015.

\title{
Biographical note
}

Michel Dutton is professor of politics at Goldsmiths, University of London. Although, perhaps, best known for Streetlife China (CUP, 1998), Dutton is the author of numerous books on China including, most recently, Policing Chinese Politics: A History (Duke, 2005) and, with Lo and Wu, Beijing Time (Harvard, 2008).

\begin{abstract}
摘要：这篇文章将中国文化大革命当作是一个在探究政治问题这课题中能 够开辟有关情感方面渠道的工具。它检视那个年代的一种艺术的技术, 并 展示它如何在权力的流动性里产生政治强度。这个技术是文革中对政治的 这概念浓缩, 并也是将情感力量转化做革命目标的企图。因为它企图将政 治导向情感面向, 而这些方法与当代艺术实践相似, 这篇文章开辟一种以 艺术为基础来研究政治的方法之可能性, 而非科学。
\end{abstract}

关键词: 文革; 方法论; 毛泽东思想; 政治; 美术; 强度

\section{References}

Bakken, Børge. 2000. The Exemplary Society. Oxford: Oxford University Press.

Beijing City Hygiene Bureau Small Leadership Group of the Revolutionary Committee of the Beijing Number Two Hospital. 1969. Mao Zedong sixiang tongshui xinyiliaofa ziliaohuibian (A Compilation of Materials on Following the Command of Mao Zedong Thought with New Medical Methods). Beijing: Beijing Health Bureau leadership small group, Beijing Number Two Hospital Revolutionary Group (internal publication).

Boym, Svetlana. 2008. Architecture of the Off-Modern. New York: Princeton Architectural Press.

Cheng, Dongsheng, and Lili Liu. 2003. Huawei zhengxiang (The Truth about Huawei). Beijing: Xiandai Zhongguo chubanshe.

Chung, Hua-Min, and Arthur C. Miller. 1968. Madame Mao: A Profile of Chiang Ch'ing. Hong Kong: Union Research Centre.

Clark, Paul. 2008. The Chinese Cultural Revolution: A History. Cambridge: Cambridge University Press.

Delueze, Gilles. 1978. "Lecture transcripts on Spinoza's 'Concept of Affect"” (Emilie and Julien Deleuze (trans.)), http://www.webdeleuze.com/php/sommaire.html. Accessed 1 April 2015.

Delueze, Gilles, and Felix Guattari. 2004. A Thousand Plateaus: Capitalism and Schizophrenia (Brian Massumi (trans.)). New York: Continuum.

Derrida, Jacques. 1997. Politics of Friendship (George Collins (trans.)). London: Verso.

Draghici, Simona. 1988. "Introduction." In Carl Schmitt (ed.), The Idea of Representation. Washington, DC: Plutarch Press, 7-25.

Dutton, Michael. 2002. "Dreaming of better times: repetition with a difference and Chinese community policing." In Tani E. Barlow (ed.), New Asian Marxism. Durham, NC: Duke University Press, 21-52.

Dutton, Michael. 2004. "Mango Mao: infections of the sacred." Public Culture 16(2), 161-186.

Dutton, Michael. 2005. Policing Chinese Politics: A History. Durham, NC: Duke University Press. 
Erickson, Britta. 2010. "The Rent Collection Courtyard, past and present." In Richard King (ed.), Art in Turmoil: The Chinese Cultural Revolution 1966-1976. Vancouver: UBC Press, 121-135.

Foucault, Michel. 1978. The History of Sexuality Part One (Robert Hurley (trans.)). New York: Pantheon Books.

Foucault, Michel. 1991. "Governmentality." In Graham Burchell and Colin Gordon (eds.), The Foucault Effect: Studies in Governmentality. Chicago: University of Chicago Press, 87-104.

Heilmann, Sebastian, and Elizabeth Perry (eds.). 2011. Mao's Invisible Hand: The Political Foundations of Adaptive Governance in China. Boston, MA: Harvard University Press.

King, Gary. 2013. "How censorship in China allows government criticism but silences collective expression," https://www.youtube.com/watch?v=hybtm4Fpljc. Accessed 23 June 2016.

King, Gary, Jennifer Pan and Margaret E. Roberts. 2013. "How censorship in China allows government criticism but silences collective expression.” American Political Science Review 107(2), 326-343.

King, Gary, Jennifer Pan and Margaret E. Roberts. 2014. "Reverse-engineering censorship in China: randomized experimentation and participant observation." Science 345(6199), 891-901.

Lee, Haiyan. 2014. The Stranger and the Chinese Moral Imagination. Stanford, CA: Stanford University Press.

Li, Shaoyan. 1965. "Xiang diaosu gongzuozhe xuexi" (Learning from the sculptural workers). Meishu 6 November, 3-5.

Lynton, Norbert. 2009. Tatlin's Tower: Monument to Revolution. New Haven, CT: Yale University Press.

Massumi, Brian. 1992. A User's Guide to Capitalism and Schizophrenia. Cambridge, MA: MIT Press.

Massumi, Brian. 1995. "The autonomy of affect." Cultural Critique 31, 83-109.

Ouyang, Zongshu. 1992. Zhongguo jiapu (Chinese Genealogies). Beijing: Xinhua chubanshe.

Said, Edward W. 1978. Orientalism. New York: Pantheon.

Schmitt, Carl. 1988. The Idea of Representation. Washington, DC: Plutarch Press.

Schmitt, Carl. 1996. The Concept of the Political (J. Harvey Lomax (trans.)). Chicago: University of Chicago.

Shklovsky, Viktor. 2005. Knights Move (Richard Sheldon (trans.)). Champagne, IL: Dalkey Archive Press.

Spinoza, Benedict de. 2015. The Ethics (R.H.M. Elwes (trans.)). Gutenberg project e-book, http:// www.gutenberg.org/files/3800/3800-h/3800-h.htm. Accessed 30 April 2015.

Strauss, Leo. 1996. "Notes on Carl Schmitt, The Concept of the Political." In Carl Schmitt, The Concept of the Political. Chicago: University of Chicago, 83-107.

Tafuri, Manfredo. 1990. The Sphere and the Labyrinth: Avant-gardes and Architecture from Piranesi to the 1970s (Pellegrino d'Acierno and Robert Connolly (trans.)). Cambridge, MA: MIT Press.

Wang, Guanyi. 1996. "Huishou 'Shouzuyuan"” (Looking back on the Rent Collection Courtyard). Diaosu 1, 38-39.

Wang, Zhi'an. 2001. Hongtian juechang (The Heavens Thundered at the Peak of Poetic Perfection). Chengdu: Tiandi chubanshe.

Wang, Zhi'an, Wang Fei and Wang Shao. 2003. Zhuangyuan miwen (The Secrets of the Manner). Sichuan: Sichuan chuban jituan.

Wedell-Wedellsborg, Anne. 2010. "Contextualizing Cai Guo-Qiang." Kontur 20, 9-18, http://kontur. au.dk/fileadmin/www.kontur.au.dk/Kontur_20/Microsoft_Word_-_VAM-WEDELL_MOD2.pdf. Accessed 20 November 2013.

Zhang, Youyun. 2005. "Lun gongqun dui nisu 'Shouzuyuan' xingqu zhuangxiang zhi zhuyao gengyuan" (The roots of the changing appreciation of the Rent Collection Courtyard in popular perceptions). Meishu yanjiu April, 46-53. 